\title{
Optimalisasi Media Pembelajaran Online Dengan Microsoft Power Point Untuk Menunjang Kinerja Staff Kelurahan
}

\author{
Linda Marlinda ${ }^{1)} \mid$ Faruq $_{\text {Aziz }}{ }^{2)} \mid$ Frisma Handayanna $^{3)} \mid$ Anton $^{4)} \mid$ Taransa Agasya Tutupoly ${ }^{5)}$ | \\ Susafa'ati ${ }^{6}$ \\ Teknik Informatika, Universitas Nusa Mandiri \\ linda.1dm@nusamandiri.ac.id,14002420@nusamandiri.ac.id, frisma.fha@nusamandiri.ac.id, \\ anton@nusamandiri.ac.id, taransa.tly@nusamandiri.ac.id, susafa.suf@nusamandiri.ac.id
}

\begin{abstract}
Abstrak: Staff Kesekretariatan Kelurahan Kebon Bawang merupakan salah satu bagian dari kelurahan kebon bawang merupakan yang bertugas merencanakan, melaksanakan pembinaan, mengarahkan dan mengendalikan penyelenggaraan bidang kesekretariatan yang meliputi administrasi keuangan, kepegawaian, rumah tangga, Peralatan administrasi umum, yang membantu mengkoordinasikan kegiatan desa. Staff Kesekretariatan saat ini mengalami permasalahan dalam membuat presentasi mempersiapkan untuk kegiatan rapat-rapat serta pembutan presentasi untuk pelaporan kegiatan di kelurahan kebon bawang, dalam hal ini mereka sudah menggunakan Microsoft Power Point namun dirasa kurang menarik dalam penyajian materi presentasi tersebut, dan belum optimal dalam pembuatan presentasi sertas kurang memahami dalam pengunaan aplikasi komputer tersebut. Staff Kesekretariatan yang merupakan unit Administrasi dari kelurahan kebon bawang diharapakan mempunyai kualitas yang baik sebagai pelayan publik. Sehingga mahir dalam penggunaan aplikasi perkantoran salah satunya yaitu Microsoft Power Point dalam penyajian presentasi kegiatan dan pelaporan kegiatan-kegiatan yang akan dilakukan dan telah dilakukan di kelurahan kebon bawang.
\end{abstract}

Kata Kunci: Optimalisasi; Pembelajaran Online; Kinerja Staff.

\section{Pendahuluan}

Kesekretariatan dapat diartikan sebagai keseluruhan rangkaian kegiatan struktural untuk pekerjaan kantor (korespondensi) dan tugas pembantuan lainnya untuk mendukung kelancaran realisasi tujuan organisasi. Oleh sebab itu yang dimaksud dengan manajemen sekretaris adalah keseluruhan proses pelaksanaan rangkaian kegiatan terstruktur untuk pekerjaan kantor dan tugas pembantuan lainnya guna mendukung kelancaran realisasi tujuan organisasi.

Staff Kesekretariatan Kelurahan Kebon Bawang merupakan salah satu bagian dari kelurahan kebon bawang. Saat ini, Kelurahan Kebon Bawang Jakarta Utara yang beralamat lengkap di Jalan Swasembada Timur Nomor 1, wilayah Jakara Utara ini telah memiliki satu unit kerja dibidang administrasi kesekretariatan berdasarkan Surat Keputusan Pembentukan Sekretariat Kelurahan Nomor 145 Tahun 2010 tertanggal 20 September 2010 yang ditandatangani langsung oleh Lurah Kebon Bawang Jakarta Utara.

Kegiatan yang dilakukan oleh Staff Kesekretariatan Kelurahan Kebon Bawang yaitu merencanakan, melaksanakan pembinaan, mengarahkan dan mengendalikan penyelenggaraan bidang kesekretariatan yang meliputi administrasi keuangan, kepegawaian, rumah tangga, perlengkapan umum ketatausahaan serta membantu mengkoordinasikan kegiatan dikelurahan. Staff Kesekretariatan saat ini sudah menggunakan Microsoft office dalam kegiatan administrasi dan pelayanan kepada masyarakat. Staff Kesekretariatan dalam kegiatan administrasi juga mempersiapkan kegiatan rapat-rapat dengan membuat presentasi, membuat presentasi untuk penjelasan kegiatan yang akan dilakukan dan pelaporan kegiatan-kegiatan yang telah dilakukan di kelurahan kebon bawang.

Staff Kesekretariatan saat ini mengalami permasalahan dalam penjelasan kegiatan dan pelaporan kegiatan yang akan dilaksanakan maupun yang telah dilakukan di kelurahan kebon bawang, dalam hal ini mereka sudah menggunakan Microsoft Power Point namun dirasa kurang menarik dalam 


\section{Dedikasi Sains dan Teknologi}

Jurnal Pengabdian Masyarakat

Volume 1, Nomor 1, Mei 2021

Doi : https://doi.org/10.47709/dst.v1i1.956

penyajian materi, belum optimal dalam pembuatan presentasi dan kurang memahami dalam pengunaan aplikasi komputer tersebut.

Staff Kesekretariatan yang merupakan unit Administrasi dari kelurahan kebon bawang diharapakan mempunyai kualitas yang baik sebagai pelayan publik. Sehingga mahir dalam penggunaan aplikasi perkantoran salah satunya yaitu Microsoft Power Point mulai dari memahami penggunaan, penyajian materi yang menarik serta mampu membuat presentasi kegiatan dan laporan kegiatan menjadi lebih optimal.

Kualitas pelayanan publik merupakan suatu kondisi dimana pelayanan mempertemukan atau memenuhi atau bahkan melebihi dari apa yang mejadi harapan konsumen dengan sistem kinerja aktual dari penyedia jasa (Warjiyono et al., 2021).

Publikasi dahulu yang berkaitanpun telah dilakukan diantaranya permasalahan yang dihadapi pada Kantor Desa Harjatani adalah pegawainya dalam hal pelayanan administrasinya belum semua mengenal dan mengetahui bagaimana cara mengoperasikan aplikasi komputer. Para pegawai belum memanfaatkan dan juga belum mahir menggunakan program-program standar di komputer terutama Microsoft Word, Microsoft Excel dan Microsoft Power Point (Haerani et al., 2020) serta pemanfaatan aplikasi Google Classroom serta menguasai dan mengetahui lebih banyak mengenai pembelajaran secara daring dengan Google Suite khususnya penggunaan Google Classroom. Pelatihan ini juga berdampak baik bagi upaya peserta untuk meningkatkan penetrasi kemajuan teknologi informasi dan komunikasi (TIK), terlihat dari respon positif yang mereka berikan selama acara berlangsung. (Marlinda et al., 2021).

Dalam kegiatan pengabdian kepada masyarakat, metode dilakukan yaitu tim pelaksana melakukan kunjungan ke mitra terlebih dahulu untuk melakukan analisis mengenai kondisi mitra, peserta yang yang akan diberi pelatihan, dan menyusun rancangan kegiatan yang akan dilakukan, selanjutnya mengadakan pelatihan, tahapan terakhir yang dilakukan yaitu tahap evaluasi. Evaluasi terhadap proses selama tahap persiapan sampai pelaksanaan pengabdian kepada masyarakat (Sunarti et al., 2019).

Bentuk kegiatan yang akan dilakukannya dalam kegiatan pengabdian masyarakat ini adalah melalui pemaparan teori dan praktek mengenai cara menggunakan microsoft power point. Teknik yang digunakan dalam menyampaikan materi pengabdian masyarakat adalah menjelaskan materi dengan menggunakan alat bantu multimedia berupa laptop dan menggunakan WhatsApp Web, modul, posttest dan pretest (Marlinda et al., 2019).

\section{Realisasi Kegiatan}

Kegiatan pengabdian masyarakat ini dilaksanakan pada:

$\begin{array}{ll}\text { Hari } & : \text { Sabtu } \\ \text { Tanggal } & : 24 \text { April } 2021 \\ \text { Pukul } & : 09.00-12.00 \text { WIB } \\ \text { Tempat Kegiatan } & : \text { Online via Zoom Meeting }\end{array}$

Kegiatan ini dihadiri oleh 44 peserta yang merupakan staff kesekretarisan dan dibuka dengan pembukaan oleh bapak Anton, M.Kom yang juga menyampaikan betapa pentingnya pengoptimalisasian perangkat lunak seperti Microsoft Power Point (Harahap \& Kurniawan, 2020) guna menunjang kinerja staff seperti terlihat pada gambar 1 . 


\section{Dedikasi Sains dan Teknologi}

Jurnal Pengabdian Masyarakat

Volume 1, Nomor 1, Mei 2021

Doi : https://doi.org/10.47709/dst.v1i1.956

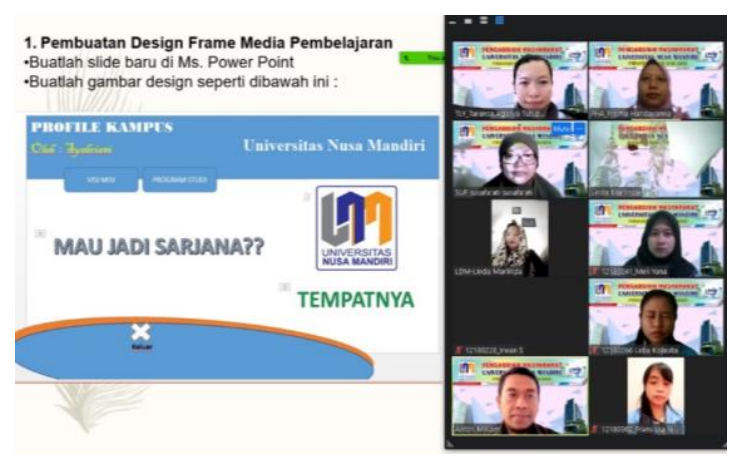

Gambar 1. Pembukaan kegiatan

Pada gambar 2, materi kegiatan disampaikan oleh ibu Frisma Handayanna M.Kom, dalam penyampaiannya pemateri memberikan alur serta tujuan dari pembelajaran ini. Selama kegiatan perserta disarankan menggunakan laptop masing-masing dan kegiatan ini disampaikan pemateri dengan sederhana, sehingga diharapkan setiap peserta mampu mengikuti dan memahami dengan baik.

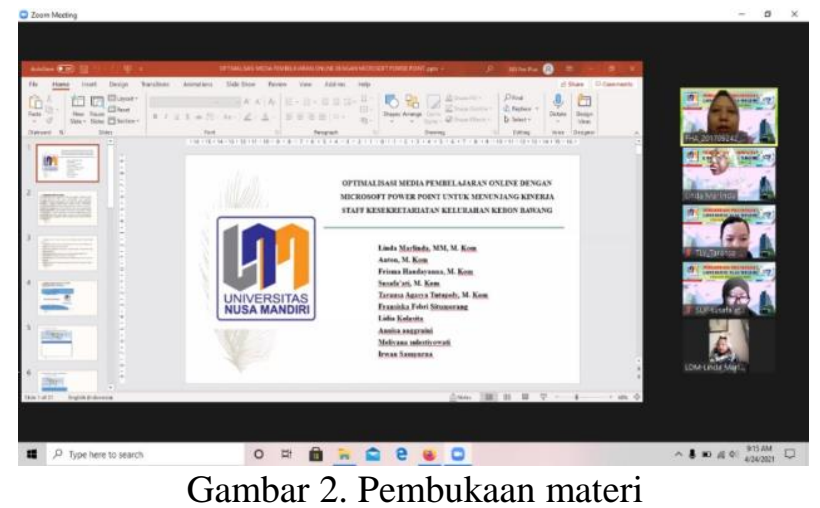

Pemateri juga pertama-tama menjelaskan terlebih dahulu tentang fungsi dan deskripsi singkat tentang Microsoft Power Point ini seperti terlihat pada gambar 3.

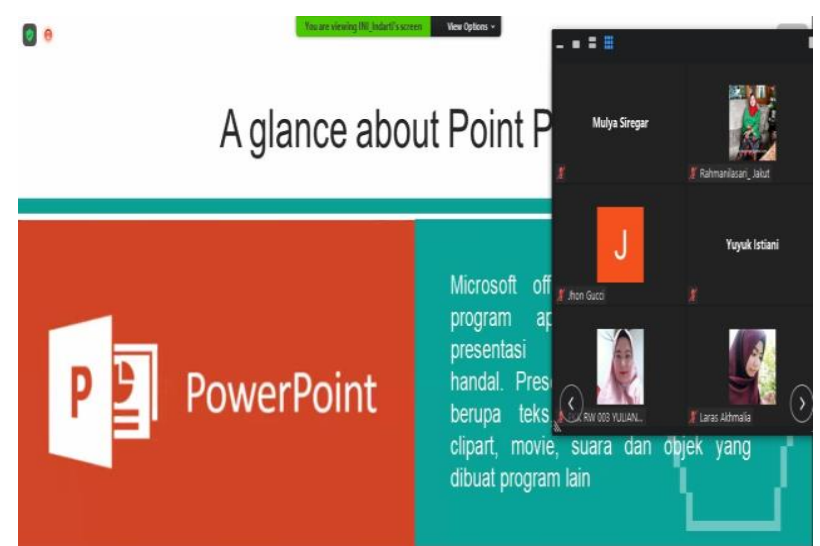

Gambar 3. Pengenalan Microsoft Power Point

Selama kegiatan, peserta dipersilahkan untuk melakukan sesi tanya jawab serta diskusi, pemateri juga mencontohkan langsung bagaimana cara membuat Power Point dari kegiatan yang ada di kelurahan kebon bawang seperti terlihat pada gambar 4. Sehingga peserta jadi semakin mengerti dan memahami dengan konsep dan contoh yang dibuat (Sundari et al., 2020). 


\section{Dedikasi Sains dan Teknologi}

Jurnal Pengabdian Masyarakat

Volume 1, Nomor 1, Mei 2021

Doi : https://doi.org/10.47709/dst.v1i1.956

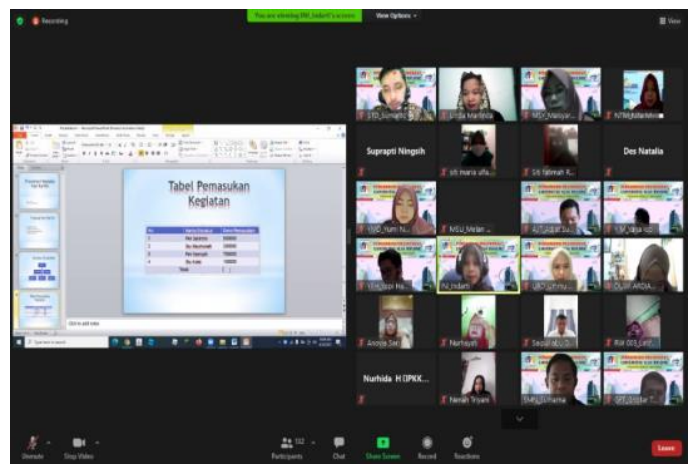

Gambar 4. Mencontohkan langsung

Kegiatan berjalan dengan baik dan lancar, peserta juga antusias dalam bertanya dan diskusi, dan kegiatan diakhiri dengan foto bersama secara online seperti terlihat pada gambar 5 .

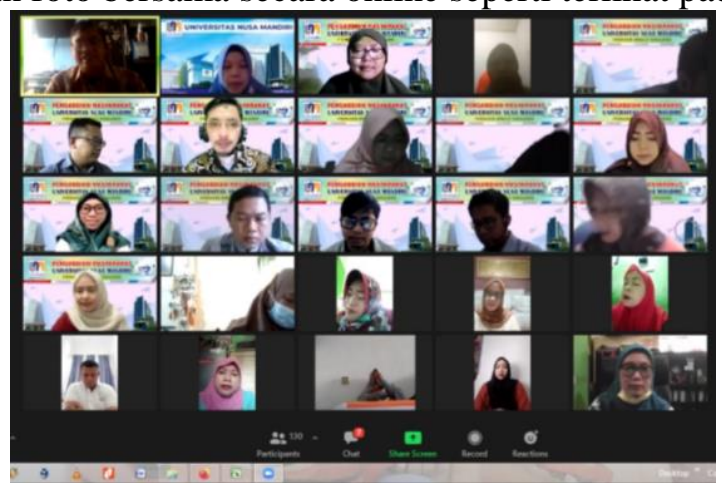

Gambar 5. Dokumentasi bersama

\section{Hasil}

Pelaksanaan kegiatan pengabdian masyarakat ini tentang optimalisasi media pembelajaran online dengan Microsoft Power Point untuk meningkatkan kompetensi kinerja staff kesekretarisan kelurahan Kebon Bawang Tanjung Priok - Jakarta Utara. Peserta terdiri dari staff kesekretarisan. Dalam kegiatan ini hasil yang dicapai dengan adanya kegiatan pengabdian masyarakat ini adalah meningkatkan kompetensi staff kesekretarisan dalam pemanfaatan optimalisasi media pembelajaran online dengan Microsoft Power Point. Kegiatan ini diharapkan bisa melakukan peningkatan pemahaman.

Kegiatan ini juga disertai dengan kuis yang diisi oleh peserta berdasarkan materi yang telah dibahas sebelum penutupan dan hasil yang diberikan dapat dilihat pada gambar 6. Hasil Quiz Pengabdian Masyarakat (PM) Universitas Nusa Mandiri (UNM).

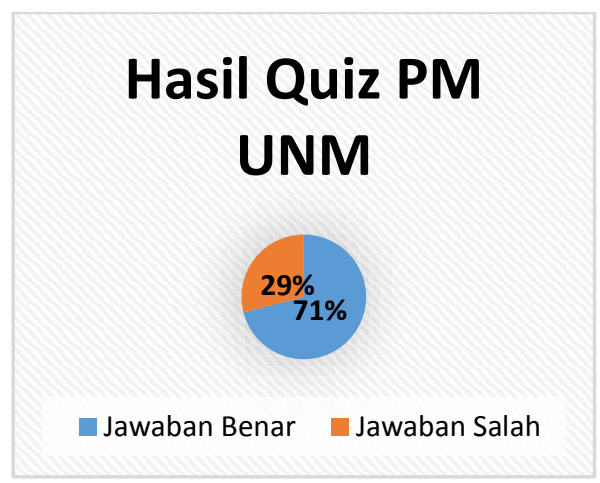

Gambar 6. Hasil quiz kegiatan 


\section{Dedikasi Sains dan Teknologi}

Jurnal Pengabdian Masyarakat

Volume 1, Nomor 1, Mei 2021

Doi : https://doi.org/10.47709/dst.v1i1.956

Dari gambar 6. Terlihat hasil pertanyaan mengenai materi sebesar $71 \%$ yang terdiri dari 44 peserta menjawab benar sehingga kegiatan ini cukup memberikan pemahaman yang baik bagi peserta. Kemudian sebelum penutupan acara setelah sesi foto bersama juga peserta diminta mengisi kuesioner yang berisi 10 pertanyaan dapat dilihat pada tabel 1 dan gambar 7 yang merupakan hasil / respon dari peserta. Kuesioner ini dilakukan sebagai bahan evaluasi penyampaian materi untuk kegiatan berikutnya.

Tabel 1. Kuesioner PM UNM

\begin{tabular}{ll}
\hline No & Pertanyaan \\
\hline P1 & $\begin{array}{l}\text { Personil/anggota yang terlibat dalam kegiatan Pengabdian Masyarakat memberikan } \\
\text { pelayanan sesuai dengan kebutuhan peserta }\end{array}$ \\
\hline P2 & Tutor menyampaikan materi kegiatan dengan jelas dan mudah dimengerti oleh peserta \\
\hline P3 & $\begin{array}{l}\text { Setiap keluhan/pertanyaan/permasalahan yang diajukan ditindaklanjuti dengan baik oleh } \\
\text { tutor yang terlibat }\end{array}$ \\
\hline P4 & $\begin{array}{l}\text { Materi yang disampaikan sesuai dengan kebutuhan peserta dalam menambah wawasan, } \\
\text { pengetahuan, keterampilan dan keahlian peserta }\end{array}$ \\
\hline P5 & Peserta mendapatkan materi kegiatan berupa modul dan soal latihan \\
\hline P6 & Peralatan untuk menyampaikan materi memadai \\
\hline P7 & $\begin{array}{l}\text { Kegiatan pengabdian masyarakat yang disampaikan bermanfaat untuk menambah wawasan, } \\
\text { pengetahuan, keterampilan dan keahlian peserta }\end{array}$ \\
\hline P8 & $\begin{array}{l}\text { Saya merasa puas dengan kegiatan pengabdian masyarakat yang diselenggarakan Universitas } \\
\text { Nusa Mandiri }\end{array}$ \\
\hline P9 & $\begin{array}{l}\text { Kegiatan pengabdian masyarakat yang diselenggarakan Universitas Nusa Mandiri sesuai } \\
\text { dengan harapan saya }\end{array}$ \\
\hline P10 & Jika kegiatan ini diselenggarakan kembali, saya bersedia untuk berpartisipasi/terlibat \\
\hline
\end{tabular}

Terlihat pada gambar 7 bahwa dari 10 pertanyaan, rata-rata peserta menjawab Ya untuk setiap pertanyaan sehingga diharapkan menjadi bahan evaluasi dan motivasi untuk kegiatan PM berikutnya.

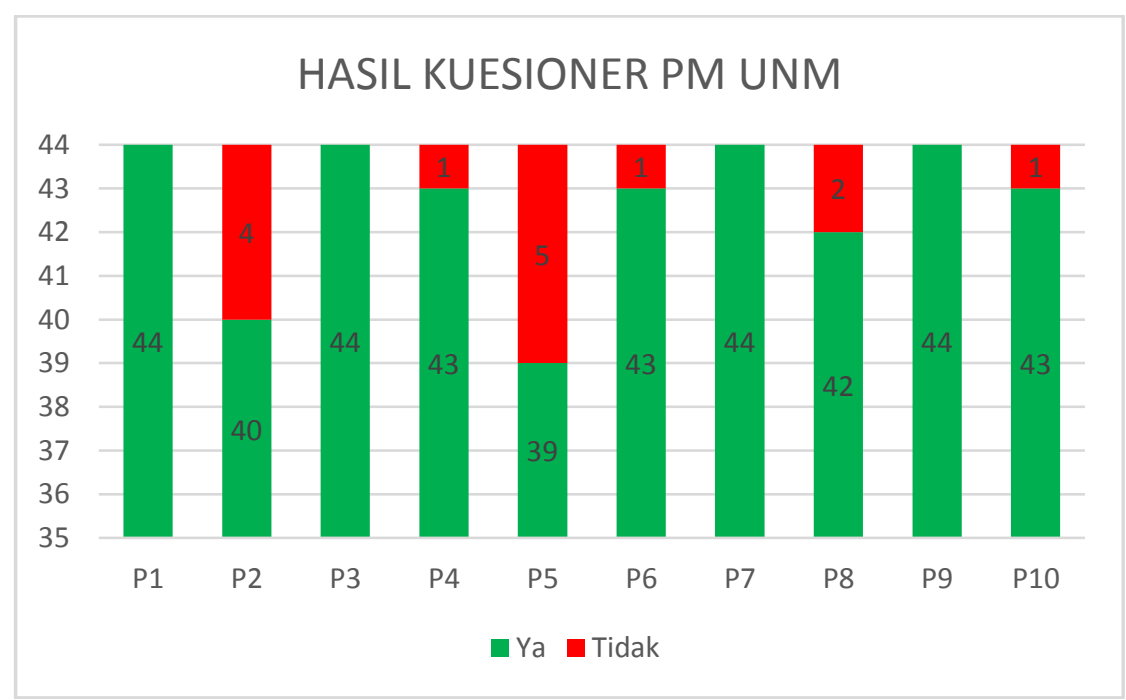

Gambar 7. Hasil Kuesioner PM

\section{Kesimpulan}

Berdasarkan dari kegiatan pengabdian masyarakat yang dilakukan secara daring dengan menggunakan zoom meeting, menyimpulkan bahasan mengenai Optimalisasi Media Pembelajaran Online dengan Microsoft Power Point Untuk Menunjang Kinerja Staff Kesekretariatan Kelurahan Kebon Bawang, kesimpulannya yaitu: 


\section{Dedikasi Sains dan Teknologi}

Jurnal Pengabdian Masyarakat

Volume 1, Nomor 1, Mei 2021

Doi : https://doi.org/10.47709/dst.v1i1.956

1. Memberikan pengetahuan pengunaan aplikasi Microsoft Power Point untuk membuat presentasi yang menarik.

2. Dari pengabdian masyarakat ini, Staff Kesekretariatan dapat mengetahui cara penggunaan salah satu aplikasi Microsoft Power Point yang dapat digunakan dalam penyajian materi kegiatan dengan menarik tentang kegiatan yang akan diadakan di kelurahan kebun bawang.

3. Dari pengabdian masyarakat ini, Staff Kesekretariatan dapat mengetahui cara penggunaan salah satu aplikasi Microsoft Power Point yang dapat digunakan secara optimal dalam penyajian pelaporan kegiatan-kegiatan yang sudah diadakan di kelurahan kebun bawang.

Adapun saran yang mungkin dapat membantu kegiatan pengapdian masyarakat yaitu:

1. Staff Kesekretariatan dapat secara optimal menggunakan salah satu aplikasi Microsoft Power Point

2. Staff Kesekretariatan harus lebih tertarik dalam penyajian materi menggunakan Microsoft Power point.

\section{Daftar Pustaka}

Haerani, R., BAHARU, R. R., \& Dkk. (2020). Pelatihan Penggunaan Aplikasi Microsoft Office Dalam Meningkatkan Pelayanan Administrasi Bagi Pegawai Kantor Desa. Journal.Unrika.Ac.Id, 4(2), 68-77. https://www.journal.unrika.ac.id/index.php/MNDBHRU/article/view/2692

Harahap, F., \& Kurniawan, H. (2020). JAMAIKA: Jurnal Abdi Masyarakat Program Studi Teknik Informatika Universitas Pamulang Pembelajaran Perangkat Lunak Perkantoran (Microsoft Word, Excel, Power Point) (Studi Kasus: Inpres 105294 Cinta Damai). JAMAIKA: Jurnal Abdi Masyarakat, 1(2), 8-14. http://openjournal.unpam.ac.id/index.php/JAMAIKA/article/view/4585

Marlinda, L., Handayanna, F., Agasya Tutupoly, T., \& Aziz, F. (2021). Pemanfaatan Google Classroom Untuk Proses Pembelajaran Siswa Sekolah Pada Masa Pandemi Covid-19. Jurnal AbdiMas Nusa Mandiri, 3(1), 17-22. https://doi.org/10.33480/abdimas.v3i1.2032

Marlinda, L., Supendar, H., Radiyah, U., Handayanna, F., Doing, L. B., \& Dan, K. T. (2019). Implementasi Microsoft Word Untuk Mengolah Laporan Kegiatan Karang Taruna dan PKK Cipinang. Jurnal Abdimas UBJ, 1(1), 61-69.

Sunarti, S., Rachmawati, S., \& Handayanna, F. (2019). Peningkatan Pendapatan Ukm Pada Hacord Gallery Dengan Aplikasi Web Marketplace E-Commerce. Jurnal Terapan Abdimas, 4(2), 166. https://doi.org/10.25273/jta.v4i2.4840

Sundari, S., Rismayanti, Khairunnisa, Damayanti, F., \& Asih, M. (2020). Cara Mudah Membuat Media Pembelajaran Interaktif Dengan Microsoft Power Point 2010 Untuk Guru SMPS Nur Ilmi | Prioritas: Jurnal Pengabdian Kepada Masyarakat. Jurnal Prioritas, 2(1). https://jurnal.harapan.ac.id/index.php/Prioritas/article/view/159

Warjiyono, W., Suryanti, E., Rousyati, R., Fatmawati, F., Tazali, I., Lisnawati, L., \& Rosihyana, R. (2021). Pelatihan Aplikasi Perkantoran Untuk Meningkatan Kualitas SDM Perangkat Desa Karangmangu. Jurnal Abdimas BSI: Jurnal Pengabdian Kepada Masyarakat, 4(1), 156-163. https://doi.org/10.31294/jabdimas.v4i1.9102 